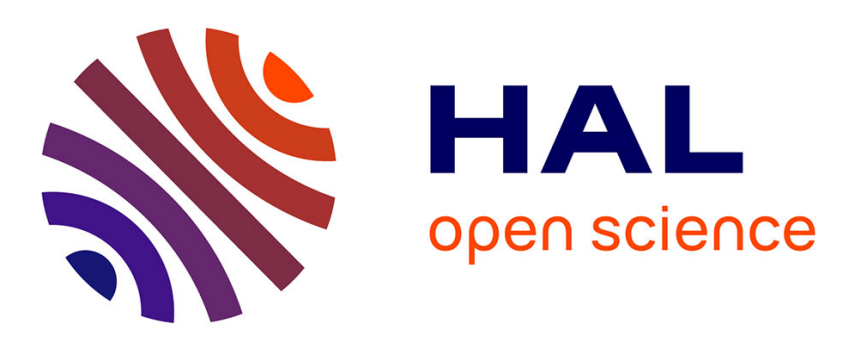

\title{
A Family Status for the European Citizen?
}

Etienne Pataut

\section{To cite this version:}

Etienne Pataut. A Family Status for the European Citizen?. Loïc Azoulai; Ségolène Barbou des Places; Etienne Pataut. Constructing the Person in EU Law - Rights, Roles, Identities, Hart Publishing, pp.311-322, 2016, 978-1782259336. halshs-02268865

\section{HAL Id: halshs-02268865 https://shs.hal.science/halshs-02268865}

Submitted on 21 Aug 2019

HAL is a multi-disciplinary open access archive for the deposit and dissemination of scientific research documents, whether they are published or not. The documents may come from teaching and research institutions in France or abroad, or from public or private research centers.
L'archive ouverte pluridisciplinaire HAL, est destinée au dépôt et à la diffusion de documents scientifiques de niveau recherche, publiés ou non, émanant des établissements d'enseignement et de recherche français ou étrangers, des laboratoires publics ou privés. 


\title{
A Family Status for the European Citizen ?
}

\author{
Etienne Pataut \\ Professor at the Sorbonne Law School (University of Paris 1)
}

\section{Working paper}

Family law is now a part of European legislation and many regulations have been adopted in this field. It was possible to adopt these regulations only by extending the competence of the Union, not to substantive family law, which to a large extent is still beyond the reach of European legislators, but to private international law. This competence, bitterly debated in France, is no longer contested, and has enabled the adoption of international judicial law or conflicts of law rules in family matters, which are so important today. There now seem to be two approaches available to family law in Europe. The first, substantive law, is national while the second, private international law, is largely European.

Between the two, however, lays a third option. Substantive Union law has long focused, albeit rather indirectly, on family law. The free movement of persons, in particular, had an effect on family law as, when extended to family members, it forced legislators to clarify what the terms meant. Similarly, the rules relating to equal treatment and non-discrimination have at times called into question the legitimacy of treating different family types differently ${ }^{1}$. On the whole, however, these rules remained relatively specific, difficult to extend beyond the specific case, which brought them into being, and as such, the influence of Union law on the family remained quite low overall.

This situation changed utterly with the introduction in Union law of a concept that at first glance was far removed from both family law and private international law: European citizenship.

At the heart of European integration since its insertion in the Treaties in 1992, European citizenship has given rise to a wealth of legal literature, as abundant as it is essential.

\footnotetext{
${ }^{1}$ On all these issues, see in particular J. Meeusen, M. Pertegas, G. Straetmans (eds.), International Family Law for the European Union, Intersentia, 2007.
} 
European citizenship is part of the stated ambition to both build a European body politic and give legal meaning to each individual's membership of the European $\operatorname{area}^{2}$. At first, the family seems to be some distance away from this objective. However, through successive interpretations, the Court of Justice has had a profound impact. In considerably enriching its content, the Court has progressively increased significant points of contact between citizenship and family law, to the extent that nowadays reasoning specific to this field must be included to understand the sources of changes in family law in Europe. Two examples will suffice to demonstrate this: the surname (Section 2) and civil status (Section 3). Before this, however, it is necessary to understand, even schematically, the links between citizenship, private international law and family law (Section 1).

\section{Citizenship, private international law and family law}

The concept of European citizen is extremely vast and often a little vague as regards its consequences. In political discourse in the Union, it is very often invoked and can be used to justify almost anything. However, in the treaty it has a precise meaning because it is the criterion for applying the rights listed in Article 20 TFUE. Of these rights, the first and most important is of course free movement; after that come the right to vote, the right to diplomatic protection and the right to petition. Naturally, the list continues to grow, because of the openended wording of Article 20, the second paragraph of which confirms that the citizens shall enjoy the rights mentioned "inter alia". Nonetheless, the rights listed are precise, limited and therefore do not form a unified legal regime - far from it.

However, from Article 20 and its predecessors, the Court of Justice has progressively built up a highly original legal regime that extends well beyond the original narrow framing of citizenship.

Indeed, in 2001, in the famous Grzelczy $k^{3}$ ruling, the Court drew up the jurisprudential standard, which it has repeated in each decision on citizenship: according to the Court, citizenship is now "the fundamental status of nationals of the Member States". In this area, all of the work of the Court of Justice over the last ten years or so has involved providing a precise legal content to this fundamental status.

\footnotetext{
2 There is extensive literature on all the above - see in particular M. Benlolo-Carabot, Les fondements juridiques de la citoyenneté européenne, Brussels, Bruylant, 2007, and D. Kochenov, "The citizenship paradigm”, 15 CYELS, (2012-13), 197-226. See also the critical assessment of the EU case law by K. Hailbronner, "Union Citizenship and Access to Social Benefits", Common Market Law Review, 42. 2005, p. 1245.

${ }^{3}$ CJEC, 20 September 2001, Grzelczyk, case C-184/99.
} 
The central concept is that of "status", which, seen from the standpoint of family law, itself refers to the idea of "personal status". These terms, however, are rarely used today, to the point where they can seem a little dated. Today, private international law is one of the only areas where the term "personal status" is used to describe the vast category of personal and family law issues. But as this category is now itself very fragmented, when the term is used, it is generally to underline its outdated nature due precisely to the category's lack of standardisation ${ }^{4}$.

In accordance with the well-known dictum whereby the categories of private international law reflect the categories of domestic law, while the category of "personal status" is tending to disappear from conflicts of law, it is because the very idea that a "status" of persons could exist in personal and family law has today been largely abandoned. There is no longer any status but different legal regimes, all corresponding to different legal situations or issues. The very idea of "personal and family status", which appears to imply that there is only one family type, makes people smile today, with family law completely liberalised and multiple family types with no hierarchy between them.

Therefore, the fact that the Court of Justice has returned to this term when referring to the European citizen may surprise some. In fact, the use of the term is deliberate but involves a profound conceptual change. The aim first and foremost is obviously political. In asserting the idea that there is a "status" of European citizen, the Court is asserting the specific legal existence of this new figure and is thus contributing to the formation of that unique body, which is also a political body: citizenship of the Union.

However, unification came about at the expense of a radical change of meaning. Status in no way reflects a unique substantive legal regime. In fact, in the Court's case law, citizenship is not only the criterion for accessing rights or a predetermined legal regime. The solution would also be incongruous in family law because here again there is no competence in family law. In this instance, status does not reflect a particular regime but merely guarantees the stability of a regime already formed. In combining freedom of movement, equal treatment and citizenship, the Court of Justice's reading has led to the increasingly broad guarantee that people can not only move around freely but that they can do so with all the family ties they have formed.

At the outset, freedom of movement, permitted people to enter and stay in the territory of another Member State. Combined with equal treatment, it allows people to access the same

\footnotetext{
${ }^{4}$ See in particular D. Bureau and H. Muir Watt, Droit International Privé, 2nd ed., PUF, 2010, no. 619, who reject the term, preferring "personal sphere" and "family sphere".
} 
social benefits as the nationals of other Member States ${ }^{5}$. Now combined with citizenship, it guarantees that any family status developed in a Member State is recognised in the other Member States. Again, this is not a particular development of family law. It is simply a means of ensuring that the rules of family law applied in a host State do not in any manner infringe the right of European citizens to move freely.

Therefore, the issue is not that of applying any one particular regime, but the recognition in a Member State of the regime applied to a citizen in another Member State.

This idea of recognition is now at the heart of methodological discussions of private international law ${ }^{6}$. Therefore, we will content ourselves with underlining just one point: in the Court of Justice - one of the leading and main instigators - the method of recognition was not developed using the tools of private international law but with those of substantive Union law. This means that applications in family law, which are the most extreme end of this case law, have been developed in view of considerations that are not directly linked to the family but rather more directly to freedoms of movement.

Therefore, in contemporary private international family law, two different methods of reasoning, complementary but different, must be reconciled.

The first is the "localising" reasoning of traditional private international law. This line of reasoning, contrary to what might have been thought when the application of the law of the country of origin was being debated, has never been abandoned. All major regulations in private international law that have been or will be adopted incorporate conflict of law rules that, while adapted, are relatively conventional: mostly bilateral conflict rules, result-oriented conflict rules at times, selecting a particular connecting factor to find the applicable law. There is nothing new here apart from judicial and administrative cooperation, which will not be discussed here. The intent is always to coordinate systems in order to reach international harmony of solutions.

However, this line of reasoning is supplemented by another: the "mobility" reasoning of the European Union, arising out of the freedoms of movement. Here, the aim is no longer an abstract aim to coordinate laws but a concrete aim to ensure possession and exercise of specific rights. The aim here is to allow a particular person to access particular rights, in the

\footnotetext{
5 Due to recent case law, this question is now under intense doctrinal scrutiny, on which see in particular D. Thym, "The elusive limits of solidarity: residence rights of and social benefits for economically inactive union citizens", Common Market Law Review 52: 17-50, 2015.

${ }^{6}$ For a summary of the discussions on this topic in Europe, see in particular P. Lagarde (dir.), La reconnaissance des situations en droit international privé, Pedone, 2013.
} 
name of freedom of movement. Simply put, with the inrush of European citizenship, this reasoning of access to rights has become more abstract, because the issue is no longer to guarantee a particular right to a particular citizen in another Member State (the right to vote for example), but more widely to allow him or her to move about without any impediment, which should be understood as implying that the citizen can move around with his or her own legal regime.

The free movement reasoning of Union law and the coordinating reasoning of private international law thus come together around a fundamentally common objective: ensuring the unity of the status of persons. European Union law readily speaks of recognition, whereas private international law tends to refer to the international harmony of solutions. But in both cases the final objective is the same: ensuring that a person who is called Dupont and is married in Germany does not become a divorced Durand in France.

Hence, both methods of reasoning complement each other and lead to a relatively profound reconstruction of the mechanisms and rules of law that allow a person to cross a border with his or her personal and family characteristics and therefore to a complete reconstruction of the rules of private international family law.

This reconstruction is not without consequences on substantive family law, even if these are as yet piecemeal. Facilitating the recognition of both decisions and situations amounts to favouring the approximation of laws, in the sense of liberalisation, as it becomes easier to obtain in one State what was difficult to obtain in one's own State. Commentators have rightly referred to divorce ${ }^{7}$ and the combination of criteria of broad competence and the liberalisation of divorce rulings has undeniably made a prohibition on divorce almost illusory in Europe. Divorce is now permissible, albeit in a more or less liberal form, in all European Union countries. The same debate is now taking place as regards the reserved portion of an estate (reserve héréditaire) and, more generally, maintaining specific national features in matters of succession after the implementation of the EU Succession Regulation ${ }^{8}$. It is too early to say exactly what effect this regulation will have on substantive succession law but there can be no doubt that it will have some. Therefore, despite the Union's lack of competence in family law, we are now witnessing if not the emergence of substantive

\footnotetext{
${ }^{7}$ B. Ancel and H. Muir Watt, "La désunion européenne : le règlement dit 'Bruxelles 2"”, Rev. Crit. 2001. 403 ; see also P. Mankowski and U. Magnus, European Commentary on the Brussels 2 regulation, Sellier, 2012.

${ }^{8}$ M. Grimaldi, “Brèves réflexions sur l'ordre public et la réserve héréditaire”, Defrénois, 2012. 755.
} 
European family law, at least the incontestable convergence of systems, facilitated by the recognition and coordination mechanisms.

However, this reconstruction primarily affects private international family law, the focus of this piece. This is what we now intend to investigate, leaving the fairly abstract terrain followed up to now to provide two well-known and oft-discussed examples of the impact of the right to freedoms of movement on private international family law: surname and civil status.

\section{The surname}

The influence of freedoms of movement on the surname is doubtless one of the most famous interactions between substantive Union law, private international law and family law and it has long attracted intense attention in the literature ${ }^{9}$.

Through the intermediary of European citizenship, the Court of Justice, wholly unexpectedly, has progressively ventured into the area of the surname.

In the first stage, the Court did not stray from its traditional economic considerations. Extending its case law to include the mutual recognition of qualifications ${ }^{10}$, it deemed that the principle of mutual recognition should be extended to civil status documents of other Member States, which as such are presumed to be consistent "unless their accuracy is seriously undermined by concrete evidence relating to the individual case in question"11; similarly, the entry of a surname in the civil registers has been challenged before the Court because poor transliteration infringed the freedom of establishment of the person concerned ${ }^{12}$. Thus, even though this constituted an intrusion by Union law into the sphere of the law of persons, case law has remained relatively measured, related to economic activity and ultimately limited to an obligation of mutual recognition of administrative deeds.

However, this trend was most significantly accelerated and profoundly transformed by the concept of European citizenship. The Garcia-Avello case ${ }^{13}$ and more especially the Grunkin-

\footnotetext{
${ }^{9}$ See on this point the premonitory reflections of M. Scherer, Le nom en droit international privé, Etude de droit comparé français et allemand, LGDJ, 2004. For a summary of the changes, see C. Kohler's recent, "La reconnaissance de situations juridiques dans l'Union européenne : le cas du nom patronymique”, in: P. Lagarde (dir.), La reconnaissance des situations en droit international privé, op. cit., p. 67.

${ }^{10}$ On this, see P. Rodière, Droit Social de l'Union Européenne, LGDJ, $2^{\text {nd }}$ ed., 2014, No. 219.

${ }^{11}$ CJEC, 2 December 1997, Dafeki, Case C-336/94: this case revolved around determining the age of a person who wished to join an early retirement scheme.

12 CJEC, 30 March 1993, Konstantinidis, Case C-168/91.

${ }^{13}$ CJEC, 2 October 2003, Garcia-Avello, Case C-148/02.
} 
Paul $^{14}$ case, both of which related to surname issues, provided the full scope of this change. The latter ruling, which we will here focus on exclusively, related to the refusal by the German authorities to recognise the name given to the child of a German couple by the Danish authorities, where the child had been born and was living. The surname given to the child by the Danish civil registration system combined both the father's and the mother's surname. The German authorities held that the issue of a name should be governed by the national law of the interested party and insisted on applying the provisions of German law, which does not allow double-barrelled surnames. Believing that the compatibility of the regulation with Union law could be challenged, the German authorities referred the question to the Court of Justice for a preliminary ruling.

The Court found in favour of the parents, basing its ruling on the then Article 18 of the Treaty establishing the European Economic Community. The rights attached to the capacity of European citizen would in effect be called into question if the child bore a different surname in two countries with both of which he had close ties. The German authorities were therefore required to recognise the surname as determined by Danish law.

This solution is of considerable importance. While the Garcia-Avello ruling could lead to substantial divergences in interpretation, the solution of the Grunkin-Paul ruling is, for its part, perfectly clear. Founded solely on citizenship, independent of non-discrimination and the difficulties inherent in dual nationality, it indeed requires a Member State to recognise a family situation legally constituted in another Member State, regardless of the conflict of laws rules of the State addressed. When exercising their freedom of movement as guaranteed under the treaty, Union citizens must be assured that their situation is permanent and any challenge to what has previously been constituted could potentially be a barrier to that situation.

Admittedly, the solution is not limitless, as has been shown by two significant Court rulings rendered in 2010 and 2011: Sayn-Wittgenstein ${ }^{15}$ and Runevič-Vardyn ${ }^{16}$. The issue in both cases was to what extent States can invoke limits to support their refusal to recognise a name or title given in another State. The first case related to a German aristocratic title, which was turned down for registration in the Austrian civil registers, the second was the refusal to transcribe a Polish name on the Lithuanian civil registers with the preferred spelling of the party concerned. In both cases, the Court acknowledged that the constitutional traditions of

\footnotetext{
${ }^{14}$ CJEC, 14 October 2008, Grunkin-Paul, Case C-353/06.

${ }^{15}$ CJEU, 22 December 2010, case C-208/09.

${ }^{16}$ CJEU, 12 May 2011, case C-391/09.
} 
States could oppose the recognition of a name or title given in another State. The reasoning used by the Court is the same as that which it generally uses in the event of an obstacle: first characterise the obstacle, then check if there is any justification for it and if this is proportionate. As this test was passed in both cases, the States were allowed to raise their objection to recognition. The aim here, therefore, is to balance the right of every citizen to have their surname recognised with the right of States to maintain their basic rules, which are a fundamental part of their national identity.

This reasoning is certainly traditional in Union law. However, it completely differs from traditional private international law, which generally reasons in the more conventional terms of conflict of laws. As the Grunkin-Paul case imposed another mode of reasoning, the exact consequence of this on the conflict rule remains to be measured. The German legislator involved in this case opted for the minimum transcription, which is now enshrined in Article 48 EGBGB. In substance, this article allows anyone whose name is governed by German law to choose the name s/he would have been given in another EU Member State, unless this choice is manifestly incompatible with the essential principles of German law.

This type of solution is perhaps overly restrictive ${ }^{17}$, particularly as it relates only to names governed by German law, whereas the requirement for recognition is in fact insensitive to this consideration and could also relate to a name subject to other laws.

The solution nevertheless takes note of the changes imposed by the Court of Justice, subject to the reservation of the "essential principles of German law". This new Article 48 thus indeed reflects a profound change of method to take account of the "fundamental status of nationals of a Member State", which constitutes European citizenship.

Thus, under these Court of Justice rulings, the status of citizen took on a more concrete meaning, which was further clarified in the Sayn-Wittgenstein and Runevič-Vardyn rulings. The surname of a citizen must imperatively be recognised but not just because of the requirements of free movement, which is closely determined by entry and residence conditions. It is also because what it as stake is the very identity of the European citizen. Beyond the technique of recognition, there is therefore a more profound requirement: enshrining the identity of citizens, an identity that must be accepted as is without modification in the host State. We can see here that although it has not entirely disappeared, conflictual reasoning has profoundly changed.

\footnotetext{
${ }^{17}$ On this analysis and the various options that were open to the German legislator, see C. Kohler, op. cit., pp. 73 et seq.
} 
This solution therefore heralds major changes and the adoption of a text on civil status seems likely to accentuate these changes even further.

\section{Civil status}

As we have seen, the Court's progressive interference in surname issues comes under the technical issues relating to civil status. The logical consequence for the Court is to facilitate recognition of European Union civil status documents that would be independent of any international agreements to which Member States might be party.

It is this fundamental point that is currently at the heart of legislative debate. Since 2010 and its initial report on European citizenship ${ }^{18}$, the Commission has aimed to simplify the administrative situation of citizens.

This proposal gave rise some months later to a green paper, whose title alone is enough to indicate its programmatic nature: "Less bureaucracy for citizens: promoting free movement of public documents and recognition of the effects of civil status" ${ }^{\prime 19}$. In turn, the green paper led to a proposal of major significance: the "Proposal for a regulation on promoting the free movement of citizens and businesses by simplifying the acceptance of certain public documents in the European Union" dated 24 April $2013^{20}$.

The proposal is highly ambitious in that it proposes to simply abolish any formal procedure in place (whether legalisation, apostille or any other certification procedure) that is currently a prerequisite to a civil status document having effect in another country. It also aims to create effective administrative cooperation and proposes a series of multilingual standard forms that could be used throughout the European Union.

The text therefore goes further than the 1961 Hague Convention, known as the Apostille Convention, which with 105 signatory states is one of the major successes of the Hague Conference. By simply abolishing any obstacle to the acceptance of civil status documents from one Member State in another Member State, the text would obviate any recourse to the Convention's mechanism. It is therefore likely to infinitely reduce the red tape which nationals of Member States have to go through when they have to produce public documents drawn up in their country of origin when going about their daily business in their country of

\footnotetext{
${ }^{18} \operatorname{COM}(2010) 603$ final.

${ }^{19} \mathrm{COM}(2010) 747$ final.

${ }^{20} \mathrm{COM}(2013) 228$ final.
} 
residence. Potentially, therefore, it fulfils very well the aims set by the Union's institutions, viz. to improve the situation of citizens in a visible and concrete manner when they exercise their freedom of movement. This justification explains the legal basis retained: Article 21(2) TFUE. Thus, building directly on European citizenship, the Commission is proposing a text which explicitly aims to promote the essential prerogative of the citizen: access to the broadest possible freedom of movement ${ }^{21}$.

Despite its incontestable ambition, the text nonetheless falls short of the Commission's initial proposal. The green paper raised two questions: the "free movement of public documents" on the one hand and the "recognition of the effects of civil status" on the other. Of these two questions, the second was evidently the most important as it aimed to go beyond simply recognising the authenticity and probative value of public documents and endeavour to give effect to the content of the legal situation recorded in the document.

Most likely due to significant political difficulties, the solution eventually retained dealt only with the first question, which the text outlines in the clearest fashion:

"It is important to stress that the proposal does not address the issue of recognition of public documents between the Member States nor does it introduce full harmonisation of all public documents existing in the Member States or situations in which they are needed in crossborder scenarios by EU citizens and businesses. The Union multilingual standard forms to be established by this proposal will not produce legal effects as regards the recognition of their content in the Member States where they will be presented"22.

Therefore, only the movement of instruments is envisaged, not that of their content. Further, the proposal says nothing about exactly what probative value should be given to a document from another Member State, nor about where any dispute on the substantive legal relationship which the document records (marriage or parentage for example) should be brought. The clear inference is that any such dispute would not be affected by this proposal and that it could be brought before any European court competent to rule on the substantive issue. The proposal relates only to the official form of the document, not the substance of the legal status of persons. It is this modesty - as well as a recurring debate on whether the concept of recognition can even be used with public documents ${ }^{23}$ - which explains why the very term

\footnotetext{
${ }^{21}$ For more extensive discussions on this issue, see: E. Pataut, "Vers un état civil européen ?" Mélanges en l'honneur de Spyridon Vrellis. Nomiki Bibliothiki, Athens, pp. 635-646.

${ }^{22} \operatorname{COM}(2013) 228$ final, 1-3-2. My italics.

${ }^{23}$ For more on this, see in particular M. Buschbaum, "La reconnaissance de situations juridiques fondées sur les actes d'état civil ?", D. 2011. 1094 and C. Nourissat, P. Callé, P. Pasqualis, P. Wautelet, "Pour la reconnaissance
} 
recognition has now been abandoned for another term, more neutral but also more vague: acceptance ${ }^{24}$.

This presentation should not, however, hide the fact that, despite its limited scope, the impact of this text will likely be much more important in the long term. A regulation on the movement of civil status documents would in fact of necessity have an impact well beyond the simple question of the probative value of the documents, in terms of the recognition of the very content of the public documents in question. There are two reasons for this.

The first and most evident relates to the very mechanism set up via the proposal. The text actually proposes to set up rules that would facilitate the movement of civil status documents to an extraordinary extent. This kind of harmonisation would naturally have an effect on the recognition of the type of situations recorded in the documents. Firstly, through the use of standardised forms, the authorities of the host State would be able to know the exact nature of the document submitted for recognition, beyond national traditions as regards civil status documents. In case of doubt, they would have the legal means to check the legality of the document with the original administration. Consequently, it is reasonable to assume that disputes relating to these documents would become even more rare than is the case today.

In fact, any remaining divergences would come under one of three headings: marriage, surname and parental name, and biological or adoptive name. As cases where marriages performed on the territory of another Member State are denied recognition are extremely rare today, it is questionable whether this is a real difficulty. True, it could become more so, with the introduction of same-sex marriages, which could trigger a public policy procedure in States that have not adopted these marriages in their own system of law.

Nonetheless, the major difficulty lies in surnames and parental name. In these areas, there remain significant differences between Member States, in terms of both substantive law and conflict of laws rules. This means that an EU citizen could have another name in another State or that parentage established in one State is not recognised in another. Under these assumptions, recognising the authenticity of a civil status document would not change anything: what would pose a problem would not be the document, which no-one doubts that it

des actes authentiques au sein de l'espace de liberté de sécurité et de justice", Petites Affiches, 4 April 2012, No. 68, p. 6. comp. E. Pataut, "La reconnaissance des actes publics dans les règlements européens de droit international privé", in: P. Lagarde (dir.), La reconnaissance des situations en droit international privé, Pedone, 2013 , p. 147.

${ }^{24}$ On the use of this term in notarial documents, see P. Callé, "L'acceptation des actes authentiques", JCP. N. 2012. 1086 . 
complies with the requirements of the country of origin, but the legal situation itself which the host country would be refusing to recognise. Thus divergence is seen to be much more profound because simple administrative cooperation could not overcome the difficulty. Nevertheless, apart from these divergences stated above, in all other areas, facilitating the movement of civil status documents would incontestably in turn facilitate the movement of the substantive situation which it records.

The second reason relates to the legal basis. It should be noted that the proposal is founded not on Article 81 TFUE, which is the usual basis in matters of private international family law, but on Articles 20 and 21 - European citizenship. Naturally, the reasons behind this are opportunity and qualified majority. The fact remains that this founding has powerful legal consequences.

If it adopted the text on such a legal basis, the European legislator would be recognising, in the most explicit way, that freedom of movement should be understood as freedom of movement with one's civil and family status. Apart from the surname, all the legal elements of this status could be implicated, including parentage and marriage. Therefore, the text on the acceptance of public documents involves more than a merely technical issue. Such a text would in fact definitively establish an extensive interpretation of freedom of movement based on citizenship, as yet limited to the Court. Beyond the controversies on the exact extent to which public documents would be recognised, in practice the regulation would establish an interpretation of EU competence that is by means self-evident. In asserting the interpretation of the Court of Justice on firm legislative bases, the text could therefore, in turn, lead to much more widespread recourse to the recognition method.

This would mean that secondary law and EU case law would complement each other to impose the substantive recognition of family situations effectively enshrined in the law of a Member State. It would no longer be necessary to digress into recognising the content of public documents. Public documents would play their essential role - a probative one, as the requirements of freedom of movement interpreted on the basis of European citizenship would then take precedence, ensuing that the substantive situation recorded in the document would indeed be recognised without challenge in the host State. Apart from the surname, it can be assumed that if the text were adopted, the refusal to recognise a parental relationship lawfully established or a marriage lawfully performed in a Member State would constitute an infringement of the free movement of citizens as interpreted by the Court and subsequently by the legislator. 
These interpretations naturally include a measure of conjecture and do not settle the most sensitive question of how public policy could or would intervene to prevent the recognition of certain situations that could raise eyebrows in the legal system of the host State (same-sex marriage, surrogacy, medically assisted reproduction, etc.).

The fact remains that adopting a text on the acceptance of civil status documents explicitly founded on the free movement of European citizens suggests that the stakes are political rather than technical. What is heralded here is not just the birth of European civil status but a true "status" for citizens who move, in the sense that they can move with their family situation intact.

These examples - particularly that regarding civil status, because of the potential it holds show the progressive influence of European Union law and, within it, European citizenship, on private international family law. As we have seen, the impact of citizenship is first and foremost one of method. In substituting the finalistic, concrete reasoning of the enjoyment of rights for the neutral, abstract reasoning of the conflict of laws, citizenship leads to the imposition of a new method - recognition. The aim is no longer simply to coordinate systems but rather to ensure in the most concrete manner possible that a European citizen who has acquired a certain status in a Member State will retain that status when crossing a border. The right guaranteed to citizens is not that they can acquire a certain status; it is that they can retain it once acquired; this status is now part of their identity and Union requirements impose that this status is respected in all other EU Member States. The fundamental status of European national is therefore a veritable right to an identity ${ }^{25}$ and it is in this sense, which we now see has fundamentally changed, that we can speak about the "personal status" of European citizens.

\footnotetext{
${ }^{25}$ On this issue, see A. Bucher, "La dimension sociale du droit international privé", Recueil des cours de l'Académie de droit international de La Haye, 2009, vol. 341, p. 282 et seq.
} 